\title{
Comparative resource use by juvenile parrotfishes in the Florida Keys
}

\author{
Karen L. Overholtzer*, Philip J. Motta \\ Department of Biology, University of South Florida, 4202 E. Fowler Ave., Tampa, Florida 33620-5150, USA
}

\begin{abstract}
Many parrotfishes (Scaridae) co-occur in mixed-species aggregations as juveniles, but diverge in resource use and social structure as adults. Focal observations of 3 juvenile parrotfishes (Scarus coeruleus, Sparisoma aurofrenatum, Sparisoma viride) were conducted on inshore patch reefs in the Florida Keys to examine feeding rates, food type, habitat use, and aggressive interactions. All species overlapped extensively in their use of space and food. Home ranges physically overlapped, and the proportion of microhabitats present within home ranges was similar for all species. Home range size increased with body size for $S$. coeruleus and $S$. aurofrenatum. Diets of all species were extremely similar. All fed selectively from the available foods and fed primarily ( $>50 \%$ total bites) on the calcareous macroalga Halimeda opuntia despite its potentially high energetic costs of procurement, low food value, and predicted avoidance. Focal individuals interacted aggressively with conspecifics, other juvenile parrotfishes, damselfishes, and occasionally grunts and wrasses. S. aurofrenatum and $S$. viride were most aggressive toward conspecifics. Aggressive interactions with adult parrotfishes were rare. Both Sparisoma spp. were chased more often by damselfishes than any other species. These findings support the growing body of evidence that herbivorous fish do not feed randomly from all potential foods. The aggressive interactions observed among juvenile parrotfishes are likely affecting their use of resources and may act as a precursor to subsequent territoriality as adults.
\end{abstract}

KEY WORDS: Foraging behavior · Habitat use A Aggression - Scaridae - Coral-reef fish · Herbivory

\section{INTRODUCTION}

The coexistence of so many ecologically similar, closely related fishes on coral reefs continues to be a topic of considerable debate in marine ecology. Detailed observation of resource use among these fishes is an essential precursor to designing the manipulative experiments necessary to quantify the relative importance of the processes that may structure reef fish communities such as competition, predation, disturbance, and recruitment (reviewed by Ebeling \& Hixon 1991). Reef fishes commonly undergo ontogenetic changes in resource use including diet (Bellwood 1988, Harmelin-Vivien 1989) and habitat use (Shulman

\footnotetext{
- Present address: Department of Zoology, Oregon State University, 3029 Cordley Hall, Corvallis, Oregon 97331-2914, USA.E-mail: overholk@bcc.orst.edu
}

\& Ogden 1987, Harmelin-Vivien 1989, Lirman 1994, Green 1996). However, there are currently no quantitative data available on how food and space requirements change during the life history of any reef fish (Robertson 1998). The intention of this study was to examine resource use in 3 species of juvenile parrotfishes (Scaridae) that co-occur in mixed-species aggregations as juveniles, but diverge significantly in resource use and social structure as adults.

Parrotfishes are a major component of the diverse assemblage of herbivorous fishes on coral reefs (reviewed by Hixon 1997) and possess the unique ability to remove all functional groups of algae (Steneck \& Dethier 1994). Although often considered to be a homogeneous group of grazing herbivores (Ogden 1976, Hay et al. 1983, Lewis 1985, 1986, Carpenter 1990), recent studies have shown considerable diversity among adult parrotfishes in terms of morphology, ecology, behavior, and habitat utilization (Bellwood \& 
Choat 1990, Bellwood 1994, Bruggemann et al. 1994a). However, data on the resource requirements of juveniles are conspicuously lacking, presumably because of difficulties in identification of individual species from congeners (Bellwood 1988).

Despite the well-documented inter-and intraspecific variation in social and mating patterns among adult parrotfishes at a range of spatial scales (Ogden \& Buckman 1973. Dubin 1981, van Rooij et al. 1996b), the potential for social interactions among juvenile parrotfishes remains unexplored. Although sexually immature, and therefore lacking the complex mating strategies of adults, juveniles are likely to be involved in aggressive interactions with potential food competitors such as confamilials or territorial damselfish (Pomacentridae). Active territorial defense by pomacentrids suggests that they compete with juvenile parrotfishes for access to food within algal mats defended by the damselfish (Low 1971, Ebersole 1977, Itzkowitz 1990). However, all previous studies of parrotfish social interactions have reported zero or low frequencies of aggressive interactions involving juveniles (Dubin 1981, McAfee \& Morgan 1996, van Rooij et al. 1996a).

Aggregations of juvenile parrotfishes are common on inshore patch reefs in the Florida Keys and typically contain Scarus iserti, Sparisoma aurofrenatum, and Sparisoma viride, and occasionally Scarus coeruleus and Sparisoma atomarium. The blue parrotfish $S$. coeruleus is among the least studied of the 12 common Caribbean scarids. Adults of this species are thought to be specialized sand-suckers, foraging directly from the sandy halos that surround patch reefs (Longley \& Hildebrand 1941). When mature, individuals form large roving groups with home ranges encompassing numerous patch reefs and may reach up to $120 \mathrm{~cm}$ in length (Böhlke \& Chaplin 1993). S. aurofrenatum, the redband parrotfish, is abundant in the Florida Keys, where terminal phase (TP) males are permanently territorial and defend a harem of females (Muñoz 1996). Its adult diet consists primarily of benthic turf algae in the Virgin Islands (Randall 1967) and mainly the calcareous macroalga Halimeda opuntia in the Florida Keys (Muñoz 1996). The stoplight parrotfish S. viride has a variable social structure throughout its geographic range, and all phases are common in the Florida Keys. Its feeding behavior is well-studied in Bonaire, where all phases fed primarily on endolithic algae and associated algal turfs (Bruggemann et al. 1994a,b, van Rooij et al. 1996a,c).

The goal of this research was to examine resource use and related social behaviors in juvenile Scarus coeruleus, Sparisoma aurofrenatum, and Sparisoma viride on inshore patch reefs in the Florida Keys, specifically addressing the following questions: (1) What are the differences in foraging behavior and habitat use among the 3 species? (2) Are these fishes feeding selectively from among the available food items, and, if so, are there interspecific differences in selectivity? (3) Is there evidence of aggressive interactions among these juvenile parrotfishes, and are these species the recipients of aggression from herbivores more frequently than non-herbivores?

\section{MATERIALS AND METHODS}

Study sites. This study was conducted on the inshore patch reefs of Coral Gardens in Hawk Channel adjacent to Lower Matecumbe Key in the upper-middle Florida Keys, USA $\left(80^{\circ} 44^{\prime} \mathrm{W}, 24^{\circ} 51^{\prime} \mathrm{N}\right)$ from April to November 1996. The average depth at this site is approximately $5 \mathrm{~m}$, and the numerous patch reefs range in size from 10 to $2000 \mathrm{~m}^{2}$. The study area consisted of 3 moderate-sized $\left(\sim 1000 \mathrm{~m}^{2}\right)$ adjacent patch reefs surrounded by halos of sand and Thalassia testudinum seagrass beds. Dominant scleractinian corals on these reefs include Diploria spp., Montastrea annularis, M. cavernosa, and Siderastrea spp., and the dominant macroalga is Halimeda opuntia.

Supplemental observations of juvenile Sparisoma viride were made on the patch reefs of Little Africa near Loggerhead Key in the Dry Tortugas National Park $\left(82^{\circ} 56^{\prime} \mathrm{W}, 24^{\circ} 38^{\prime} \mathrm{N}\right)$ in October of 1996 . This area is shallower than Coral Gardens, with a mean depth of approximately $2.5 \mathrm{~m}$. Thickets of dead Acropora cervicornis are dominant at this site, and live coral cover (mostly Montastrea annularis and Porites asteroides) is minimal. Halimeda opuntia is the dominant macroalga. Scarids were less abundant at this site; only 3 of the 5 species of juveniles common at Coral Gardens were present (Scarus iserti, Sparisoma aurofrenatum, S. viride).

Field observations. All behavioral observations were conducted using SCUBA between 10:00 and 16:00 $\mathrm{h}$, and were made only when horizontal visibility was at least $3 \mathrm{~m}$. Twelve focal individuals each of Sparisoma aurofrenatum and Sparisoma viride, and 7 individuals of Scarus coeruleus were observed. ( $S$. coeruleus was less abundant at Coral Gardens than the other 2 species.) The identities of focal individuals were determined by relative size and characteristic markings. Time of day was recorded for all observations, and total length (TL) of each fish was determined to the nearest $5 \mathrm{~mm}$. Lengths of focal fishes were repeatedly verified by comparing length estimates to a variety of background landmarks. Size ranges of focal individuals were similar for all 3 species and ranged from 40 to $100 \mathrm{~mm}$ for $S$. aurofrenatum (mean $\mathrm{TL} \pm \mathrm{SD}$, $65 \pm 17), 40$ to $90 \mathrm{~mm}$ for $S$. viride $(60 \pm 15)$, and 40 to $95 \mathrm{~mm}$ for $S$. coeruleus $(59 \pm 20)$. 
Foraging and social behavior. After a 5 min habituation period, focal individuals were followed at a distance of $\sim 1 \mathrm{~m}$ for $15 \mathrm{~min}$ to record all occurrences of feeding. Each bite, the substrate from which it was taken, and the number of bites per foraging bout were recorded. A foraging bout was defined as a series of bites taken from the same location where the only observable movement of the fish is that required to reapply the jaws to the substrate. Substrate categories included 2 upright foliose macroalgae $(>15 \mathrm{~mm}$ frond height), Halimeda opuntia and Dictyota spp.; large algal turfs ( $\geq 10 \mathrm{~mm}$ frond height) referred to as 'turf'; sedimented algal turf that consisted of sedimented sparse algal turfs ( $<10 \mathrm{~mm}$ frond height); turtle grass Thalassia testudinum; and sand. Both large and sparse algal turfs were multispecific assemblages containing crustose, filamentous, and unicellular algae of all major divisions. An 'other' category encompassed all substrates from which few bites were taken, including crustose coralline algae, sponges, and coprophagy.

During each $15 \mathrm{~min}$ focal observation period, we also recorded the occurrence of all social interactions involving the focal individual. The frequency per minute of all overt aggressive and agonistic behaviors (including chases, mouth to mouth displays, dorsal fin raising, and caudal or pelvic fin flaring) was tallied on slates. Participants in these encounters were identified to species, and the color phase was recorded for all scarids.

Habitat use. After completing collection of feeding and social interaction data, we continued to follow the focal individual to determine the size of its home range. Home ranges for these fishes were defined as the area through which the fish ranged habitually, and were measured for a period of at least $60 \mathrm{~min}$, or until no further increase in area occurred. We dropped weights with attached fluorescent surveyor's tape at every point where the fish changed direction, and weights were repositioned as necessary until the individual no longer strayed beyond the boundary created by the markers, suggesting that the entire home range of the individual had been mapped. Each side of the resultant polygon was then measured to the nearest centimeter with a tape measure, and a compass heading determined for each edge. We redrew each home range using Designer Version 3.1 (Micrografx 1992) and measured its area in square meters using SigmaScan/Image Version 1.2 (Jandel Scientific 1994). Home range data were collected for all 7 Scarus coeruleus focal individuals, and 10 each of Sparisoma aurofrenatum and Sparisoma viride.

We determined the percentage cover of microhabitats (living coral; rubble; gorgonians; sponges; sand; macroalgae Halimeda opuntia and Dictyota spp.; large algal turfs; sparse sedimented algal turfs; and seagrass Thalassia testudinum) in each home range using mul- tiple chain-link transects that were $2.0 \mathrm{~m}$ and 90 links in length (Porter 1972). Five to eight replicate transects were taken per home range, and relative abundances of microhabitats within each home range were determined from the mean of these replicates. Sample sizes were determined using a performance curve of the standard deviation of the percentage cover of each substrate type as a function of sample size, and varied to accommodate differences in home range sizes among individuals (Brower et al. 1989). Transect location was randomized within home ranges, and the number of links covering each microhabitat type was used to estimate its relative cover within that home range

Statistical analyses. All analyses were performed with the SigmaStat Version 2.0 statistical software package (Jandell Scientific 1995). Data were tested for normality using the Kolmogorov-Smirnov test and for homogeneity of variances using the Levene median test at $\alpha=0.05$ before performing any parametric statistics. Data that did not meet the assumptions for parametric statistics after transformation were analyzed by nonparametric methods. Mann-Whitney tests were used to compare total bites, bites to particular substrata, home range size, and microhabitats available within home ranges for Sparisoma viride from the Dry Tortugas with those from Coral Gardens. Because none of these variables was significantly different between sites, data for $S$. viride from the 2 locations were pooled in all subsequent analyses.

One-way ANOVA was used in lieu of 2-way (1 repeated factor) ANOVA for among- and within-species comparisons of feeding and aggression variables because of violations of parametric assumptions. The only 2-way nonparametric ANOVA (Scheirer-Ray-Hare extension of the Kruskal-Wallis test) does not allow for a repeated measures factor, and Zar (1996) cautions strongly against its use. To ensure that there was no significant interaction between factors, 2-way (1 repeated factor) ANOVA was used to test log-transformed data that were normal, but heteroscedastic. Lacking interaction, within-species data were analyzed by separate 1 -way nonparametric repeated measures ANOVA (Friedman's $\chi^{2}$ ) and among-species comparisons were conducted using a parametric 1way ANOVA or Kruskal-Wallis 1-way ANOVA (KW) on ranks when appropriate. These methods were employed for comparisons of the number of bites on each food item, microhabitat data, the relative frequency of feeding, intra-, and interspecific aggression, and focal individuals as aggressors or recipients of aggression. Kruskal-Wallis 1-way ANOVA was also used to compare home range size and rugosity among species. Student-Neuman-Keuls' (SNK) test or Dunn's multiple comparisons (DMC) tests (for cases of unequal sample 
sizes) were used for multiple comparisons of all significant ANOVA effects ( $p<0.05)$.

Linear least-squares regressions were used to examine the relationship between total bites or home range size (log-transformed) and fish size (TL) within each species. A $\chi^{2}$ test was used to compare the frequency distribution of foods available within home ranges ('expected') to those fed upon ('observed') to test the selectivity of feeding within each species. The frequency of foods available was determined from chain-transect data. Coral, gorgonians, and rubble were excluded from the 'expected' frequencies because no individuals were observed feeding from them.
A

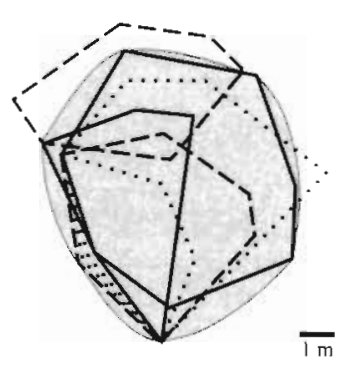

B $\quad---S$. aurofrenatum

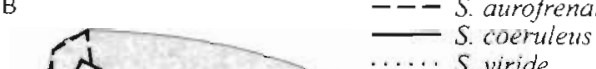

Fig. 1. Overlapping home ranges of individual juvenile Scarus coeruleus, Sparisoma aurofrenatum, and Sparisoma viride for all fishes observed on 2 patch reefs at Coral Gardens, Florida. Shaded areas indicate the extent of the patch reefs

\section{RESULTS}

\section{General behavior}

Aggregations of juvenile parrotfishes were common on the patch reefs of Coral Gardens and were numerically dominated by Scarus iserti, followed by fewer numbers of Sparisoma aurofrenatum and Sparisoma viride, and an occasional Scarus coeruleus or Sparisoma atomarium. These groups typically included 10 or fewer individuals and were highly fluid, with fish joining and leaving as often as every $30 \mathrm{~s}$. Identifiable individuals were seen repeatedly at the same locations over several weeks, and therefore exhibited some degree of day-to-day site attachment. All 3 species spent most of their time feeding (>90\%) and often swam around the edges of their home ranges, maintaining a swimming position of no more than $1 \mathrm{~m}$ above the reef. Occasionally entire groups or individuals would make short forays off the reefs into the seagrass beds, feed on Thalassia testudinum, and then return to the reef.

\section{Habitat use}

Home ranges of all 3 species of juveniles overlapped extensively (Fig. 1). Mean home range size was not significantly different among the 3 species ( $\mathrm{KW}, \mathrm{H}_{2}=$ $4.8, \mathrm{p}=0.09$ ). Home ranges of Scarus coeruleus tended to be the largest $\left(35.8 \pm 18.3 \mathrm{~m}^{2}, \mathrm{n}=7\right)$, followed by those of Sparisoma aurofrenatum $\left(23.6 \pm 26.0 \mathrm{~m}^{2}, \mathrm{n}=\right.$ $10)$, and Sparisoma viride $\left(17.6 \pm 13.0 \mathrm{~m}^{2}, \mathrm{n}=10\right)$ Within species, home range size increased with body size (TL), and this trend was significant for $S$. coeruleus and $S$. aurofrenatum (Fig. 2). For these species the relationship between body size and home range size
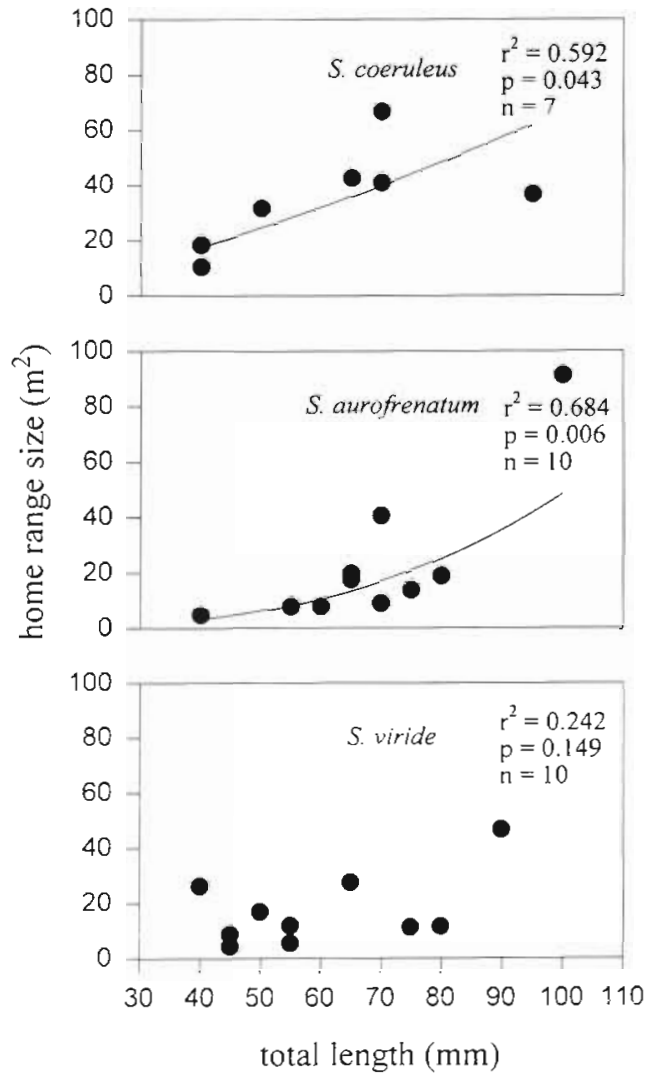

Fig. 2. Home range size $\left(\mathrm{m}^{2}\right)$ as a function of fish size (mm TL) for juvenile Scarus coeruleus, Sparisoma aurofrenatum, and Sparisoma viride. For $S$. coeruleus and $S$. aurofrenatum, regression variables based on linear least-squares regression. of log-transformed variables ( $S$. coeruleus: $\log y=-1.044+$

$1.435 \log x_{i}$ S. aurofrenatum: $\left.\log y=-4.114+2.922 \log x\right)$

was best described by regression of log-transformed variables. Home range size did not increase significantly with body size in Sparisoma viride. 
The relative percentage cover of microhabitats in the home ranges of each species was similar (Table 1). Home ranges of Scarus coeruleus contained similar amounts of Halimeda optuntia, sedimented algal turfs (SAT), hard coral, and sand. This was the only species that utilized substantial portions of the sandy halos that surround the patch reefs of Coral Gardens in its home ranges. Home ranges of Sparisoma aurofrenatum contained significantly more $H$. optuntia than any other microhabitat, followed by similar amounts of SAT and hard coral. Certain individuals of this species included portions of Thalassia testudinum beds in their home ranges. Home ranges of Sparisoma viride had similar cover of $H$. optuntia and SAT followed by hard coral cover. All individuals of this species limited their home ranges to portions of the patch reef itself. There were no differences among species in the percentage cover of any one microhabitat (ANOVA, p > $0.05)$

\section{Foraging}

Total bites taken from all food types combined per 15 min observation period were not significantly different among the 3 species (ANOVA, $F_{2,28}=2.45, \mathrm{p}=$ $0.11)$, although the statistical power to detect differences was low, 0.27, implying that small sample size may have precluded rejection of the null hypothesis (Zar 1996). Scarus coeruleus took $116.0 \pm 21.6$ bites per 15 min (mean $\pm \mathrm{SD}, \mathrm{n}=7$ ), Sparisoma viride took $103.1 \pm 26.1$ bites $(\mathrm{n}=12)$, and Sparisoma aurofrenatum took $88.6 \pm 29.5$ bites $(n=12$ ). The total number of bites per $15 \mathrm{~min}$ was not related to TL for any species (linear least-squares regression, $\mathrm{p}>0.05$ ). Therefore, feeding rate did not vary predictably over the size ranges observed.

Total bites taken from particular substrata were significantly different within each species (Fig. 3; Friedman's repeated measures ANOVA, Scarus coeruleus: $\chi_{6}^{2}=22.4, p=0.001$; Sparisoma aurofrenatum: $\chi_{6}^{2}=6.0$, $\mathrm{p}<0.001$; Sparisoma viride: $\chi_{6}^{2}=62.4, \mathrm{p}<0.001$ ). All 3

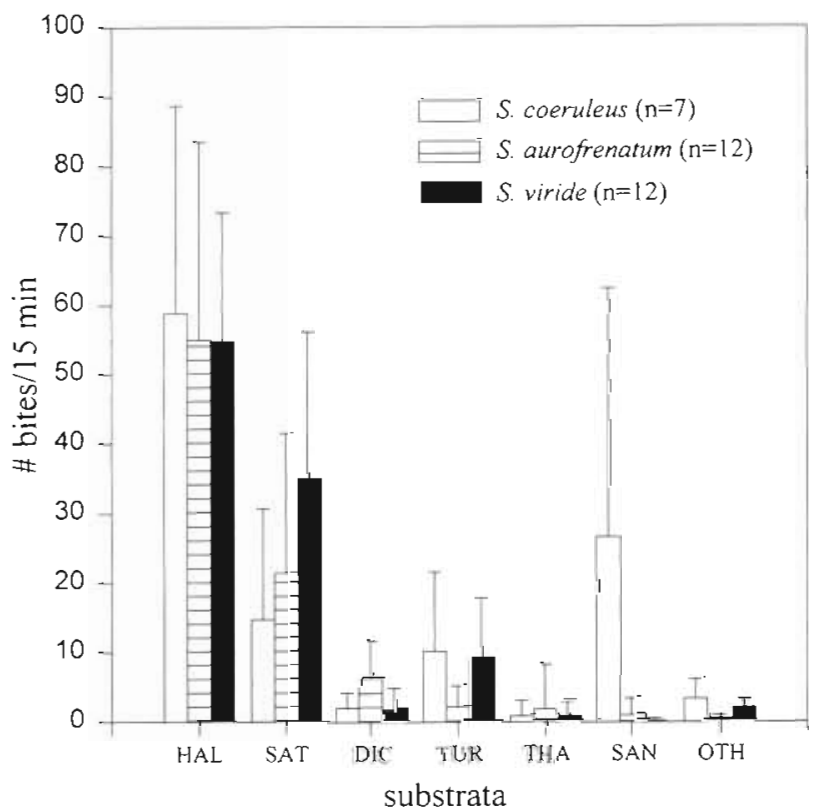

Fig. 3. Mean ( \pm SD) number of bites per 15 min observation period on various substrata for juvenile Scarus coeruleus, Sparisoma aurofrenatum, and Sparisoma viride. HAL: Halimeda opuntia; SAT: sedimented algal turf; DIC: Dictyota spp.; TUR: turf algae; THA: Thalassia testudinum; SAN: sand; OTH: other substrata including sponge, bare coralline algae, and coprophagy

species took significantly more bites from Halimeda opuntia than any other food type (SNK, $\mathrm{p}<0.05)$. Bites from $H$. opuntia constituted at least half of all bites taken by each species (mean bites per $15 \mathrm{~min} \pm \mathrm{SD}$; $S$. coeruleus: $58.9 \pm 31.9, S$. aurofrenatum: $55.0 \pm 28.5, S$. viride: $54.7 \pm 18.7$ ). Visible bite scars remained on $H$. opuntia blades after feeding by these juveniles, indicating that they were feeding on the tissues of the macroalga itself rather than scraping only epiphytes. After H. opuntia, S. coeruleus fed equally from all substrata, with the exception of Thalassia testudinum, from which it took fewer bites than any other food. $S$. aurofrenatum took more bites from SAT than from Dictyota spp. followed by similar numbers of bites from

Table 1. Percent cover of microhabitats present in juvenile home ranges of each parrotfish species. $\chi^{2}$ values from Friedman's nonparametric repeated measures ANOVA. Underlined means are not significantly different $(p>0.05$, nonparametric StudentNeuman-Keuls). $\cdots p<0.001$

\begin{tabular}{|c|c|c|c|c|c|c|c|c|c|c|}
\hline \multirow[t]{2}{*}{ Species } & \multicolumn{9}{|c|}{ Microhabitats } & \multirow[t]{2}{*}{$\chi^{2} \gamma$} \\
\hline & $\begin{array}{c}\text { Hali- } \\
\text { meda } \\
\text { opuntia }\end{array}$ & $\begin{array}{l}\text { Sed- } \\
\text { imented } \\
\text { algal turf }\end{array}$ & $\begin{array}{l}\text { Hard } \\
\text { coral }\end{array}$ & Sand & $\begin{array}{c}\text { Dictyota } \\
\text { spp. }\end{array}$ & $\begin{array}{c}\text { Large } \\
\text { turf }\end{array}$ & $\begin{array}{l}\text { Thalassia } \\
\text { testudi- } \\
\text { num }\end{array}$ & $\begin{array}{c}\text { Coral } \\
\text { rubble }\end{array}$ & Other & \\
\hline Scarus coeruleus & 29.1 & 25.3 & 14.4 & 22.6 & 1.2 & 3.0 & 2.1 & 0.0 & 2.3 & $35.72 \cdots$ \\
\hline Sparisoma aurofrenatum & 39.9 & $\underline{21.6}$ & 14.2 & 10.3 & 4.5 & 2.9 & 2.9 & 0.8 & $\underline{2.9}$ & $4.48^{\cdots}$ \\
\hline Sparisoma viride & 37.5 & 29.6 & 13.9 & 7.0 & 2.6 & 1.6 & 1.1 & 3.4 & 3.3 & $49.40^{\cdots}$ \\
\hline
\end{tabular}


Table 2. Relative abundances (\%) of food types available in home ranges, and relative frequencies (\%) of bites taken from each food type for each parrotfish species. The relative frequency of foods available was compared with the relative frequency of bites taken from each food type using $\chi^{2}$

\begin{tabular}{|c|c|c|c|c|c|c|c|c|c|}
\hline \multirow[t]{2}{*}{ Species } & \multicolumn{7}{|c|}{ Food types } & \multirow[t]{2}{*}{$\chi_{6}^{2}$} & \multirow[t]{2}{*}{$\mathrm{p}$} \\
\hline & $\begin{array}{c}\text { Hali- } \\
\text { meda } \\
\text { opuntia }\end{array}$ & $\begin{array}{c}\text { Sed- } \\
\text { imented } \\
\text { algal turf }\end{array}$ & Sand & $\begin{array}{c}\text { Dictyota } \\
\text { spp. }\end{array}$ & $\begin{array}{l}\text { Large } \\
\text { turf }\end{array}$ & $\begin{array}{c}\text { Thalassia } \\
\text { testudi- } \\
\text { num }\end{array}$ & Other & & \\
\hline \multicolumn{10}{|c|}{ Scarus coeruleus } \\
\hline Available & 34.1 & 29.7 & 26.5 & 1.4 & 3.5 & 2.5 & 2.3 & & \\
\hline Eaten & 50.5 & 12.6 & 23.0 & 1.7 & 8.7 & 0.7 & 2.8 & 27.40 & $<0.001$ \\
\hline \multicolumn{10}{|c|}{ Sparisoma aurofrenatum } \\
\hline Available & 47.5 & 25.7 & 12.3 & 5.4 & 3.5 & 3.5 & 2.3 & & \\
\hline Eaten & 62.5 & 24.4 & 1.1 & 7.1 & 2.5 & 2.1 & 0.3 & 17.74 & $<0.01$ \\
\hline \multicolumn{10}{|c|}{ Sparisoma viride } \\
\hline Available & 47.5 & 36.1 & 8.5 & 3.2 & 2.0 & 1.3 & 3.2 & & \\
\hline Eaten & 52.2 & 33.8 & 0.2 & 2.4 & 8.8 & 0.6 & 2.0 & 33.32 & $<0.001$ \\
\hline
\end{tabular}

turf, T. testudinum, sand, and other substrata. S. viride took more bites from SAT than turf, less from other substrata, and the fewest bites from Dictyota spp., $T$. testudium, and sand. Among-species comparisons of the number of bites per 15 min on individual food items were not significant for major food items (Fig. $3 ; \mathrm{H}$. opuntia or SAT; KW, p > 0.05). However, differences were apparent for turf ( $\left.\mathrm{KW}, \mathrm{H}_{2}=8.8, \mathrm{p}=0.01\right)$ and sand (KW, $H_{2}=10.5, \mathrm{p}=0.005$ ). Both $S$. coeruleus and $S$. viride took more bites from turf algae than $S$. aurofrenatum (DMC, $\mathrm{p}<0.05)$. S. coeruleus fed more often from sand than either of the other species (DMC, $p<$ $0.05)$.

The relative frequency of bites taken from different substrata was compared with the relative abundance of those substrata in the home ranges of each species. This comparison indicated that the diet of all 3 species was significantly different from that expected under random food selection (Table 2). Scarus coeruleus preferred Halimeda opuntia and large turf algae and avoided sedimented algal turf. Sparisoma aurofrenatum also selected $H$. opuntia and avoided bites to bare sand. Sparisoma viride took bites from $H$. opuntia approximately in proportion to its abundance, selected large turf algae, and avoided taking bites from sand. The proportion of bites taken from all other substrata were similar to their relative abundances in the environment.

\section{Aggression}

Focal individuals of all 3 species of juveniles were aggressive towards conspecifics, other juvenile parrotfishes, damselfishes, and occasionally towards grunts and wrasses (Table 3, Fig. 4). Aggression directed by juveniles at adult parrotfishes was never observed, with the exception of interactions with initial phase (IP) Scarus iserti, a relatively small parrotfish with an average size of $7.5 \mathrm{~cm}$ TL (Robertson \& Warner 1978). Adults of this species were not distinguished from juveniles. Among species, there were no significant differences in the amount of aggression directed towards herbivores (ANOVA, $F_{2,28}=0.64, \mathrm{p}=0.54$ ) or non-herbivores $\left(\mathrm{KW}, H_{2}=4.6, \mathrm{p}=0.10\right)$. For these comparisons, herbivores included all parrotfishes and damselfishes. Within species, both Sparisoma aurofrenatum and Sparisoma viride were more aggressive towards herbivores than non-herbivores (paired $t$-test, $S$. aurofrenatum: $t_{11}=3.78, p=0.003 ;$ S. viride: $t_{11}=3.29, p=0.007$ ). Within the category of herbivorous fishes, $S$, aurofrenatum and $S$. viride were significantly more aggressive towards conspecifics than other parrotfishes or damselfishes (KW, S. aurofrenatum: $H_{3}=10.5, p=0.015 ; \mathrm{S}$. viride: $\left.H_{3}=9.3, \mathrm{p}=0.025 ; \mathrm{SNK}, \mathrm{p}<0.05\right)$.

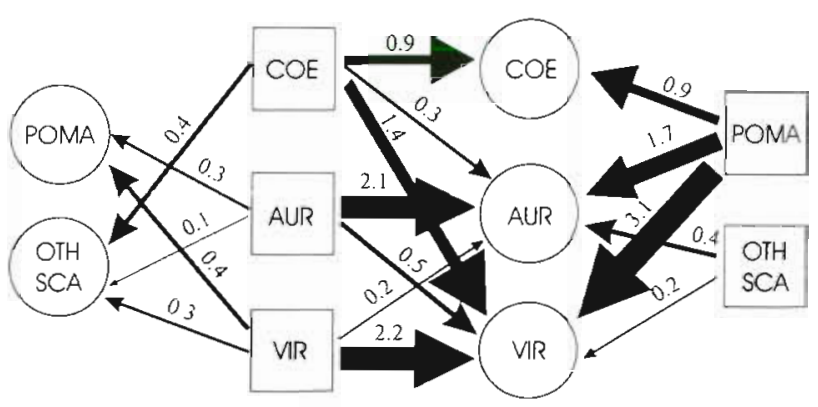

Fig. 4. Frequency of aggression observed between focal juvenile Scarus coeruleus (COE), Sparisoma aurofrenatum (AUR), and Sparisoma viride (VIR) and conspecifics, other scarids (OTH SCA), and pomacentrids (POMA). Circles represent individuals receiving aggression and squares represent the aggressors Arrow widths are proportional to mean number of interactions per 15 min. Interactions between conspecifics are the sum of focal individuals as aggressors and recipients 
Table 3. Amount of aggression directed by focal individuals towards other fishes $(A)$ and that received by focal individuals from other fishes (B). Mean number of aggressive interactions ( $\pm 1 \mathrm{SD}$ ) per $15 \mathrm{~min}$ shown for families, and total numbers of observations shown for each species. - indicates no interactions observed. $p<0.05$ (Student Neuman Keuls: within species comparisons by family); ${ }^{\dagger} p<0.05$ (Dunn's Multiple Comparisons: among species comparison)

\begin{tabular}{|c|c|c|c|}
\hline & $\begin{array}{c}\text { Scarus } \\
\text { coeruleus }\end{array}$ & $\begin{array}{c}\text { cal individu } \\
\text { Sparisoma } \\
\text { aurofre- } \\
\text { enatum }\end{array}$ & $\begin{array}{l}\text { als } \\
\quad \text { viride }\end{array}$ \\
\hline \multicolumn{4}{|c|}{ A. Focal fishes as aggressors toward: } \\
\hline Conspecifics & $0.7 \pm 1.3$ & $1.6 \pm 1.6^{\circ}$ & $1.1 \pm 1.2^{\circ}$ \\
\hline Scaridae & $0.4 \pm 0.5$ & $0.3 \pm 0.6$ & $0.4 \pm 0.5$ \\
\hline Scarus coeruleus & 5 & - & - \\
\hline S. iserti & 3 & 1 & 3 \\
\hline Sparisoma aurofrenatu & um 2 & 19 & 2 \\
\hline S. viride & 10 & 6 & 13 \\
\hline Pomacentridae & - & $0.3 \pm 0.6$ & $0.4 \pm 1.0$ \\
\hline Stegastes fuscus & - & 3 & 2 \\
\hline S. variabilis & - & - & 3 \\
\hline Other families & $0.3 \pm 0.5$ & $0.3 \pm 0.5$ & 0 \\
\hline Haemulon spp. & - & 2 & - \\
\hline Halichoeres spp. & 2 & 2 & - \\
\hline Total & $1.4 \pm 1.6$ & $2.4 \pm 2.0$ & $1.9 \pm 2.0$ \\
\hline \multicolumn{4}{|c|}{ B. Focal fishes as recipients from: } \\
\hline Conspecifics & $0.1 \pm 0.4$ & $0.7 \pm 1.5$ & $1.0 \pm 1.5$ \\
\hline Scaridae & $0.1 \pm 0.4$ & $0.6 \pm 0.8$ & $0.7 \pm 1.0$ \\
\hline Scarus coeruleus & 1 & 2 & 10 \\
\hline S. iserti & - & 2 & 2 \\
\hline Sparisoma atomarium & - & 1 & - \\
\hline S. aurofrenatum & - & 8 & - \\
\hline S. viride & - & 2 & 13 \\
\hline Pomacentridae & $0.9 \pm 0.9$ & $1.7 \pm 2.3$ & $3.0 \pm 1.6^{\circ}$ \\
\hline Stegastes fuscus & 1 & 8 & 8 \\
\hline S. leucostictus & 1 & 6 & 16 \\
\hline S. variabilis & 4 & 6 & 11 \\
\hline S. partitus & - & - & 2 \\
\hline Other families & $0.3 \pm 0.5$ & $0.3 \pm 0.9$ & $0.4 \pm 0.7$ \\
\hline Haemulon spp. & 1 & - & 2 \\
\hline Halichoeres spp. & - & 4 & 1 \\
\hline Total & $1.3 \pm 0.5$ & $3.3 \pm 3.1$ & $5.1 \pm 2.9^{\dagger}$ \\
\hline
\end{tabular}

Focal individuals were the recipients of aggression from conspecifics, other juvenile parrotfishes, damselfishes, grunts, and wrasses (Table 3, Fig 4). Juvenile parrotfishes rarely received aggression from adult parrotfishes. Exceptions included 2 chases of juvenile Sparisoma aurofrenatum by IP conspecifics and chases or displays by IP Scarus iserti. Juvenile Sparisoma viride were the recipients of aggression more often than the other 2 species and were the recipients of aggression more often than they were aggressive towards other fishes (2-way ANOVA, species: $F_{2,56}=$ $3.81, \mathrm{p}=0.03$; behavior: $F_{1,56}=4.48, \mathrm{p}=0.04$; species $\mathrm{x}$ behavior: $F_{2,56}=2.68, \mathrm{p}=0.08$; DMC, $\mathrm{p}<0.05$ ). All 3 species received similar amounts of aggression from non-herbivores ( $\mathrm{KW}, \mathrm{H}_{2}=0.7, \mathrm{p}=0.712$ ). Both $\mathrm{S}$. aurofrenatum and $S$. viride received more aggression from herbivores than non-herbivores (paired t-test, $S$. aurofrenatum: $t_{11}=2.54, p=0.028 ; S$. viride: $t_{11}=5.52$, $\mathrm{p}<0.001$ ). Sparisoma viride was the recipient of aggression from herbivores more frequently than either $S$. coeruleus or $S$. aurofrenatum (ANOVA, $F_{2,28}=4.60$, $\mathrm{p}=0.03$; SNK, $\mathrm{p}<0.05)$. Within the category of herbivorous fishes, $S$. viride received significantly more aggression from damselfishes than either conspecifics or other parrotfishes $\left(\mathrm{KW}, \mathrm{H}_{3}=17.8, \mathrm{p}<0.001\right)$.

\section{DISCUSSION}

\section{Overlap in use of space}

Use of space on the reef is clearly not partitioned among these 3 species of juvenile parrotfish in terms of physical overlap of home ranges or microhabitats present within home ranges. However, on a larger scale, subtle variations are apparent among species. Scarus coeruleus is the only species that includes substantial portions of the sandy halos that surround the patch reefs of Coral Gardens in its home ranges, and many Sparisoma aurofrenatum include portions of the Thalassia testudium beds adjacent to reefs in their home ranges. Juvenile Sparisoma viride never venture away from the reef proper, which may be related to an increased risk of predation over sand or seagrass. The juvenile coloration of this species ( 3 rows of white spots on a dark red background) is distinct from all other small parrotfishes on these reefs (pale, striped pattern) and is perhaps more likely to be conspicuous against a sandy background than to the reef proper.

Home range size may be influenced by numerous factors including the density of intra- or interspecific competitors, and the distribution and quality of food, shelter, and mating sites (Ebersole 1980, Hixon 1980b, Norman \& Jones 1984, Tricas 1989, Grant 1993). Home range size increases with body size within juvenile size classes for Scarus coeruleus and Sparisoma aurofrenatum, and home ranges measured for juveniles in this study are considerably smaller than those recorded for conspecific adults. Therefore, juvenile parrotfishes may increase their use of space on the reef as they grow. As adults, S. aurofrenatum and Sparisoma viride often defend all-purpose territories used for feeding, shelter, and reproduction (Dubin 1981, Clavijo 1982, Bruggemann et al. 1994a,c, Muñoz 1996). However, as sexually immature juveniles, it is most likely not feasible for these small fishes to exclusively defend an area from all intruders. The mean home range size of juvenile $S$. aurofrenatum in this study $\left(24 \mathrm{~m}^{2}\right)$ is smaller 
than that of IP conspecifics in Barbados ( 39 to $99 \mathrm{~m}^{2}$ ) (Dubin 1981). Territory sizes of TP S. aurofrenatum have been variable among sites. Clavijo (1982) estimated territory size to be $88 \mathrm{~m}^{2}$ in Puerto Rico, Dubin (1981) reported a range from 141.8 to $215.2 \mathrm{~m}^{2}$ in Barbados, and the mean territory size at Coral Gardens, Florida is $240 \mathrm{~m}^{2}$ (Muñoz 1996). Home ranges of juvenile $S$. viride are also much smaller (mean $=17.6 \mathrm{~m}^{2}$ ) than adult territories in Bonaire which ranged from 300 to $500 \mathrm{~m}^{2}$ (van Rooij et al. 1996b).

\section{Dietary overlap and selectivity of feeding}

There is little evidence for resource partitioning of food by these species. Spatial segregation of individual bites does not exist because all 3 species would often feed side by side from the same patch. Mixed-species foraging aggregations of these juveniles did not separate into individual species when feeding as seen among members of large Scarus iserti core-species schools in Panama (Ogden \& Lobel 1978). The diets of all 3 juvenile parrotfishes consist primarily $(>50 \%)$ of Halimeda opuntia. This calcareous green macroalga (Chlorophyta) is both chemically and structurally defended. The younger portions of Halimeda spp. contain the highest concentrations of secondary terpenoid compounds (Paul \& Fenical 1983, Hay et al. 1988), which have been shown to deter grazing in the bucktooth parrotfish Sparisoma radians, as well as numerous other parrotfishes and surgeonfishes (Lewis 1985, Hay 1991). The older portions are low in food value, heavily calcified, and thought to be highly resistant to herbivory (Littler \& Littler 1980, Hay et al. 1988). Juveniles of all 3 species studied fed predominantly from older, structurally defended portions of $H$. opuntia and left visible bite scars. In addition, both Scarus coeruleus and Sparisoma aurofrenatum fed more often from $H$. opuntia than would be expected under random food selection.

The prevalence of Halimeda opuntia in the diet of Scarus coeruleus is particularly interesting because none of the 45 members of the genus Scarus has ever been known to consume upright foliose macroalgae or seagrasses (Randall 1967, Sano et al. 1984, Wolf 1985, Bellwood \& Choat 1990, Bruggemann 1994, p. 179 190, Bruggemann et al. 1994c). Juvenile S. coeruleus also feed occasionally from the seagrass Thalassia testudinum. Adults of this species are thought to be specialized sand-suckers that forage directly from sandy bottoms (Longley \& Hildebrand 1941). Adults of 4 Scarus spp. from the Great Barrier Reef also fed from bare sand (Bellwood \& Choat 1990). Although all juvenile $S$. coeruleus in this study included patches of bare sand in their home ranges, they did not selectively take bites from this substrate and instead fed from a variety of substrata including $H$. opuntia, multispecific algal turfs, and $T$. testudinum. This suggests a potential ontogenetic trend toward specialization in the diet of this species from a juvenile feeding on a variety of foods to a more specialized adult that feeds primarily from sand.

The diet of juvenile Sparisoma aurofrenatum is remarkably similar to that of conspecific adults at the same study site. Terminal phase S. aurofrenatum took an average of 54 bites per 15 min on Halimeda opuntia (Muñoz 1996), and the corresponding mean for juveniles was 55 bites. Overall feeding rate is only slightly higher for juveniles than adults ( 89 vs 75 total bites per $15 \mathrm{~min}$ ). This species fed predominantly on seagrass in Barbados (Dubin 1981) and Panama (McAfee \& Morgan 1996). The latter study found macroalgae such as Halimeda spp to be more important in the diet of larger S. aurofrenatum, and cited mechanical limitations of the jaw as the probable cause of the ontogenetic shift. Juveniles in this study (4 to $10 \mathrm{~cm}$ TL) clearly demonstrated no such functional constraints, and diets are remarkably similar for adults and juveniles at this site in the Florida Keys.

The feeding habits of juvenile Sparisoma viride are similar to those of conspecifics studied elsewhere. Juveniles of this species feed from Halimeda opuntia as often as would be expected by chance and selectively from large algal turfs. All phases of $S$, viride primarily took bites from multispecific algal turfs in Panama (McAfee \& Morgan 1996) and fed primarily on endolithic algae, and selectively fed from large turfs and macroalgae (Bruggemann et al. 1994a,b, van Rooij et al. $1996 a, c)$. The combined cover of large algal turfs and macroalgae is considerably less in all zones on the fringing reefs in these studies ( 3.0 to $7.7 \%)$, and macroalgae are dominated by Phaeophyta rather than Chlorophyta such as Halimeda spp. (Bruggemann et al. 1994a). Therefore, taking into account the considerable differences between the 2 habitats, the diet of juvenile $S$. viride at Coral Gardens is comparable to that found at other Caribbean sites

The diets of these juvenile parrotfishes support the growing body of evidence that herbivorous fish are not randomly feeding from all potential food items they encounter Selectivity among food types under natural conditions has been demonstrated for several scarid species (Wolf 1983, Bruggemann et al. 1994a,c, Muñoz 1996). In contrast, Dubin (1981) found that 3 parrotfishes (Scarus iserti, S. taeniopterus, and Sparisoma aurofrenatum) in Barbados fed on substrates in proportion to their abundance in the environment. McAfee \& Morgan (1996) also found that 5 parrotfishes in Panama generally fed non-selectively. However, the latter study determined food availability on an entire 
reef rather than in the home ranges of individual species, and all species may not include all microhabitats in their home ranges.

\section{Potential for social structure among juveniles}

Focal individuals of all 3 species of juveniles are involved in aggressive interactions with conspecifics, other juvenile parrotfishes, damselfishes, and occasionally grunts and wrasses. In contrast, Dubin (1981) observed no occurrences of juvenile parrotfishes as aggressors during $155 \mathrm{~h}$ of observation in Barbados. Likewise, McAfee \& Morgan (1996) observed only 4 'competitive, non-sexual interactions' between parrotfishes in Panama after hundreds of hours of observation. The discrepancy between these studies and the present one may be explained by actual differences among sites (e.g. fish density, whether resources are limiting, relative importance of competition) or simply methodological differences. Observational methods (such as those used in the 2 former studies) that do not involve substantial sampling of focal individuals are more likely to overlook less frequent behaviors such as aggressive interactions. Aggression directed towards juveniles by adult parrotfishes was never observed in this study, with the exception of infrequent interactions with IP Scarus iserti. The lack of aggression by adults contradicts patterns exhibited by chaetodontids, embiotocids, and pomacentrids in which adults aggressively defend territories from juveniles (Hixon 1980a, 1981, Reese 1991, Harrington 1993).

As aggressors, juveniles tend to chase conspecific juveniles more often than other fishes, but are the recipients of aggression primarily from damselfishes. Aggressive interactions are most likely correlated with the degree of overlap in ecological requirements (Myrberg \& Thresher 1974, Choat \& Bellwood 1985). Based on the high degree of overlap in the use of space and food among these 3 species, we would expect them to display aggression toward one another as often as toward conspecifics. However, both Sparisoma aurofrenatum and Sparisoma viride are more aggressive toward conspecifics than any other parrotfishes. More subtle differences in resource requirements may exist among these species than were detected by this study. Alternatively, juveniles may recognize conspecifics as potential competitors with whom they will begin to establish a dominance hierarchy in preparation for territoriality as adults. Interspecific defense of an area by herbivores probably involves learning and may be influenced by early chance encounters with particular species (Choat \& Bellwood 1985). Our results indicate that juvenile parrotfishes selectively displayed aggression toward conspecifics, challenging the idea that naïve juvenile reef fishes chase a broader range of species than adults (Harrington \& Losey 1990).

Numerous authors have noted frequent chases of parrotfish (including juveniles) by damselfishes (Low 1971, Ebersole 1977, Dubin 1981, Itzkowitz 1990, van Rooij et al. 1996a). Itzkowitz \& Slocum (1995) showed that the attack intensity of Stegastes leucostictus against Scarus iserti was correlated with the total biomass of algae that the pomacentrid was defending. This implies defense of the food itself, rather than space. Attacks by damselfishes reduce the area in which these juveniles can feed, and may make it easier for predators to capture juveniles that are distracted by having to avoid territorial herbivores (Sweatman \& Robertson 1994). At our study site, damselfishes frequently chase juvenile parrotfishes from their territories, but there is no evidence of aggression by damselfishes toward adult parrotfishes (Muñoz 1996, K. Overholtzer pers. obs.).

\section{Implications for community structure}

The coexistence of ecologically similar, closelyrelated fishes on reefs has been explained by 4 major classes of hypotheses including: (1) niche diversification through competition, (2) the competitive lottery hypothesis, (3) recruitment limitation, and (4) predation or disturbance limitation (reviewed by Ebeling \& Hixon 1991). These 3 juvenile parrotfishes show no evidence of resource partitioning in terms of either food or space. Therefore, these observations do not support conventional models of niche diversification through past or present interspecific competition. Alternatively, resources may not be limiting for these juveniles, or these fishes are competing and a nonequilibrium mechanism such as limitation by recruitment, abiotic disturbance, or predation is allowing them to coexist.

\section{Conclusions}

There is little evidence for substantial resource partitioning of space or food among juvenile Scarus coeruleus, Sparisoma aurofrenatum, and Sparisoma viride on patch reefs in the Florida Keys. Moreover, the behavior of these fishes challenges conventional wisdom in at least 2 ways. (1) These juveniles selectively exploited a heavily calcified food source (Halimeda opuntia) despite its potentially high energetic costs of procurement, low food value, and predicted avoidance by herbivores (Littler \& Littler 1980, Lewis 1985, Hay et al. 1988, Hay 1991). (2) Focal individuals disproportionately displayed aggression toward conspecifics, 
challenging the hypothesis that juvenile reef fishes chase a broader range of species than adults, and were the recipients of aggression primarily from other herbivorous fishes.

Although juveniles do not remove as much biomass per bite as larger scarids, their relative abundance, high feeding rates, and selective foraging may contribute to a substantial effect on the distribution and abundance of benthic algae (reviewed by Hixon 1997). Future research should concentrate on the experimental manipulation of densities of territorial pomacentrids and manipulation of juvenile parrotfish to determine their relative effects on the demography and spatial distribution of larger age classes of parrotfish.

Acknowledgements. We thank S. Bell, M. Hixon, J. Ogden, and $M$. Robinson for constructive comments on various drafts of the manuscript; S. Binard, K. Choe, T. Curtis, D. Motta, N. Noone, T. Pledger, S. Schuler, and J. T. Streelman for generous field assistance; R. Muñoz for insights on experimental design; and the staff of the Keys Marine Laboratory for logistical support. This research was supported by the Lerner Gray Fund for Marine Research, Theodore Roosevelt Memorial Fund, the Florida Institute of Oceanography, and the University of South Florida. This paper is from a thesis submitted by K.L.O. in partial satisfaction of the requirements for a Master's degree in zoology from the University of South Florida.

\section{LITERATURE CITED}

Bellwood DR (1988) Ontogenetic changes in the diet of early post-settlement Scarus species (Pisces: Scaridae). J Fish Biol 33: 213-219

Bellwood DR (1994) A phylogenetic study of the parrotfishes family Scaridae (Pisces: Labroidei), with a revision of genera. Rec Aust Mus 20(Suppl): 1-86

Bellwood DR, Choat JH (1990) A functional analysis of grazing in parrotfishes (family Scaridae): the ecological implications. Environ Biol Fish 28:189-214

Böhlke JE, Chaplin CC (1993) Fishes of the Bahamas and adjacent tropical waters, 2 nd edn. University of Texas Press, Austin, TX

Brower JE, Zar JH, von Ende CN (1989) Field and laboratory methods for general ecology, 3rd edn. WC Brown Publishers, Dubuque, IA

Bruggemann JH (1994) Parrotfish grazing on coral reefs: a trophic novelty. $\mathrm{PhD}$ dissertation, University of Groningen, Groningen

Bruggemann JH, van Oppen MJH, Breeman AM (1994a) Foraging by the stoplight parrotfish Spanisoma viride. I. Food selection in different, socially determined habitats. Mar Ecol Prog Ser 106:41-55

Bruggemann JH, Begeman J, Bosma EM, Verburg P, Breeman AM (1994b) Foraging by the stoplight parrotfish Sparisoma viride. II. Intake and assimilation of food, protein, and energy. Mar Ecol Prog Ser 106:57-71

Bruggemann JH, Kuyper MWM, Breeman AM (1994c) Comparative analysis of foraging and habitat use by the sympatric Caribbean parrotfish Scarus vetula and Sparisoma vinde (Scaridae). Mar Ecol Prog Ser 112:51-66

Carpenter RC (1990) Partitioning herbivory and its effects on coral reef algal communities. Mar Biol 104:79-86

Choat JH, Bellwood DR (1985) Interactions among herbivo- rous fishes on a coral reef: influence of spatial variation. Mar Biol 89:221-234

Clavijo IE (1982) Distribution, reproductive biology, and social structure of the redband parrotfish, Sparisoma aurofrenatum (Valenciennes). PhD dissertation, University of Puerto Rico, Mayaguez

Dubin RE (1981) Social behavior and ecology of some Caribbean parrotfish (Scaridae). PhD dissertation, University of Alberta, Edmonton

Ebeling AW, Hixon MA (1991) Tropical and temperate reef fishes: a comparison of community structures. In: Sale PF (ed) The ecology of fishes on coral reefs. Academic Press, San Diego, CA, p 509-563

Ebersole JP (1977) The adaptive significance of interspecific territoriality in the reef fish Eupomacentrus leucostictus. Ecology 58:914-920

Ebersole JP (1980) Food density and territory size: an alternative model and a test on the reef fish Eupomacentrus leucostictus. Am Nat 115:492-509

Grant JWA (1993) Whether or not to defend? The influence of resource distribution. Mar Behav Physiol 23:137-153

Green AL (1996) Spatial, temporal, and ontogenetic patterns of habitat use by coral reef fishes (Family Labridae). Mar Ecol Prog Ser 133:1-11

Harmelin-Vivien ML (1989) Implications of feeding specialization on the recruitment processes and community structure of butterflyfishes. Environ Biol Fish 25:101-110

Harrington ME (1993) Aggression in damselfish: adult-juvenile interactions. Copeia 1993:67-74

Harrington ME, Losey GS (1990) The importance of species identification and location on interspecific territorial defense by the damselfish, Stegastes fasciolatus. Environ Biol Fish 27:139-145

Hay ME (1991) Fish-seaweed interactions on coral reefs: the effects of herbivorous fishes and adaptations of their prey. In: Sale PF (ed) The ecology of fishes on coral reefs. Academic Press, San Diego, CA, p 96-119

Hay ME, Colburn T, Downing D (1983) Spatial and temporal patterns in herbivory on a Caribbean fringing reef: the effects on plant distribution. Oecologia 58:299-308

Hay ME, Paul VJ, Lewis SM, Gustafson K, Tucker J, Trindell RN (1988) Can tropical seaweeds reduce herbivory by growing at night? Diel patterns of growth, nitrogen content, herbivory, and chemical versus morphological defenses. Oecologia 75:233-245

Hixon MA (1980a) Competitive interactions between California reef fishes of the genus Embiotoca. Ecology 61:918-931

Hixon MA (1980b) Food production and competitor density as the determinants of feeding territory size. Am Nat 115: $510-530$

Hixon MA (1981) An experimental analysis of territoriality in the Californa reef fish Embiotoca jacksonı (Embiotocidae). Copeia 1981:653-665

Hixon MA (1997) Effects of reef fishes on corals and algae. In: Birkeland $C$ (ed) Life and death of coral reefs. Chapman and Hall, New York, p 230-248

Itzkowitz M (1990) Heterospecific intruders, territoriaI defense and reproductive success in the beaugregory damselfish. J Exp Mar Biol Ecol 140:49-59

Itzkowitz M, Slocum CJ (1995) Is the amount of algae related to territorial defense and reproductive success in the beaugregory damselfish? Mar Behav Physiol 24:243-250

Lewis SM (1985) Herbivory on coral reefs: algal susceptibility to herbivorous fishes. Oecologia 65:370-375

Lewis SM (1986) The role of herbivorous fishes in the organization of a Caribbean reef fish community. Ecol Monogr 56:183-202 
Lirman D (1994) Ontogenetic shifts in habitat preferences in the three-spot damselfish, Stegastes planifrons (Cuvier), in Roatan Island, Honduras. J Exp Mar Biol Ecol 180: $71-81$

Littler MM, Littler DS (1980) The evolution of thallus form and survival strategies in benthic marine macroalgae: field and laboratory tests of a functional form model. Am Nat $116: 25-44$

Longley WH, Hildebrand SF (1941) Systematic catalogue of the fishes of Tortugas, Florida with observations on color, habits, and local distribution. Publs Carnegie Inst 34: $205-220$

Low RM (1971) Interspecific territoriality in a pomacentrid reef fish, Pomacentrus flavicauda Whitley. Ecology 52: $648-654$

McAfee ST, Morgan SG (1996) Resource use by five sympatric parrotfishes in the San Blas Archipelago, Panama. Mar Biol 125:427-437

Muñoz RC (1996) Social behavior and foraging ecology of Sparisoma aurofrenatum and $S$. chrysopterum (Perciformes: Scaridae) in the Florida Keys. MSc thesis, University of South Florida, Tampa, FL

Myrberg AA, Thresher RE (1974) Interspecific aggression and its relevance to the concept of territoriality in reef fishes. Am Zool 14:81-96

Norman MD, Jones GP (1984) Determinants of territory size in the pomacentrid reef fish, Parma victoriae. Oecologia $61: 60-69$

Ogden JC (1976) Some aspects of herbivore-plant relationships on Caribbean reefs and seagrass beds. Aquat Bot 2 : 103-116

Ogden JC, Buckman N (1973) Movements, foraging groups, and diurnal migrations of the striped parrotfish Scarus croicensis Bloch (Scaridae). Ecology 54:589-596

Ogden JC, Lobel PS (1978) The role of herbivorous fishes and urchins in coral reef communities. Environ Biol Fish 3: 49-63

Paul V, Fenical W (1983) Isolation of Halimedatrial: chemical defense adaptations in the calcareous reef-building alga Halimeda. Science 221:747-749

Porter JW (1972) Patterns of species diversity in Caribbean reef corals. Ecology 53:745-748

Randall JE (1967) Food habits of reef fishes of the West Indies Stud Trop Oceanogr, Miami 5:665-847

Editorial responsibility: Otto Kinne (Editor), Oldendorf/Luhe, Germany
Reese ES (1991) How behavior influences community structure of butterflyfishes (family Chaetodontidae) on Pacific coral reefs. Ecol Intl Bull 19:29-41

Robertson DR (1998) Implications of body size for interspecific interactions and assemblage organization among coralreef fishes. Aust J Ecol 23:252-257

Robertson DR, Warner RR (1978) Sexual patterns in the labroid fishes of the western Caribbean, II: the parrotfishes (Scaridae). Smithson Contr Zool 255:1-26

Sano M, Shimizu M, Nose Y (1984) Food habits of teleostean reef fishes in Okinawa Island, southern Japan. Bull 25, University Museum, University of Tokyo, Tokyo

Shulman MJ, Ogden JC (1987) What controls tropical reef fish populations: recruitment or benthic mortality? An example in the Caribbean reef fish Haemulon flavolineatum Mar Ecol Prog Ser 39:233-242

Steneck RS, Dethier MN (1994) A functional group approach to the structure of algal-dominated communities. Oikos $69: 476-498$

Sweatman H, Robertson DR (1994) Grazing halos and predation on juvenile Caribbean surgeonfishes. Mar Ecol Prog Ser 111:1-6

Tricas TC (1989) Determinants of feeding territory size in the corallivorous butterflyfish, Chaetodon multicinctus. Anim Behav 37:830-841

van Rooij JM, de Jong E, Vaandrager F, Videler JJ (1996a) Resource and habitat sharing by the stoplight parrotfish, Sparisoma viride, a Caribbean reef herbivore. Environ Biol Fish 47:81-91

van Rooij JM, Kok JP, Videler JJ (1996b) Local variability in population structure and density of the protogynous reef herbivore Sparisoma viride. Environ Biol Fish 47:65-80

van Rooij JM, Kroon FJ, Videler JJ (1996c) The social and mating system of the herbivorous reef fish Sparisoma viride: one-male versus multi-male groups. Environ Biol Fish 47:353-378

Wolf NG (1983) Behavioral ecology of herbivorous reef fishes in mixed-species foraging groups. PhD dissertation, Cornell University, Ithaca, NY

Wolf NG (1985) Food selection and resources partitioning by herbivorous fishes in mixed-species groups. Proc 5th Int Coral Reef Congr 4:23-28

Zar JH (1996) Biostatistical analysis, 3rd edn. Prentice Hall, Englewood Cliffs, NJ

Submitted: April 14, 1998; Accepted: October 19, 1998 Proofs received from author(s): January 26, 1999 